\title{
Duane Armitage
}

The University of Scranton

\section{Luther's 'Metaphysics' in Heidegger's 'Beiträge}

\section{Abstract}

This essay argues that Luther's "metaphysics" is present in Heidegger's Beiträge zur Philosophie (Contributions to Philosophy), a text many consider to be Heidegger's second magnum opus. I argue that Luther's "metaphysics" is present in Heidegger's Contributions in primarily two ways: (1) there is a Lutheran structure (of existential categories) that Heidegger appropriated not only in Being and Time, but also much earlier in his lectures on St. Paul from the 1920s, of responding to a call and converting in anxious anticipation toward a futural not-yet (what Heidegger calls "the last god"); and (2) Contributions' project concerns overcoming metaphysics, which involves first thinking through to metaphysics' conditions for possibility, which means recognizing the "ironic nature" of beyng via what Heidegger calls "thinking concealment," the logic of which originates in Luther's attacks on not only Greek metaphysics, but upon Judaism and the Mosaic law as well.

\section{KeYwords}

Heidegger, Luther, St. Paul, ontotheology, deconstruction 
As the title of this essay suggests, I would like to argue that Luther's "metaphysics" is present and at work in Heidegger's Beiträge zur Philosophie (Contributions to Philosophy), a controversial, but important text in the Heidegger cannon, a text that many argue is Heidegger's second magnum opus, as it is in this text that nearly every major theme of Heidegger's later philosophy (in and around the Kehre) presents itself, albeit at times in inchoate forms. Given the enigma that is Heidegger's Beiträge, I will begin by offering a brief outline of the project of Contributions to Philosophy, before tying this project explicitly with the thinking of Luther. As I begin, one will likely notice how "Lutheran" the project is from its inception. The thesis of my essay, however, is as follows: Luther's "metaphysics" is present in Heidegger's Contributions in primarily two ways: (I) there is a Lutheran structure (of existential categories), that Heidegger appropriated not only in Being and Time, but also much earlier in his lectures on St. Paul from the I92os (The Phenomenology of Religious Life), of responding to a call and converting (turning) in anxious anticipation toward a futural not-yet (in Contributions this is what Heidegger calls "the last god"); and (2) Contributions' project concerns overcoming metaphysics, but overcoming metaphysics in such a way that involves first thinking through to metaphysics' conditions for possibility (i.e. deconstructing it)—which means recognizing the "ironic nature" of beyng, via what Heidegger calls "thinking concealment," the logic of which originates in Luther's attacks on not only Greek metaphysics, but upon Judaism and the Mosaic law as well. But, first, let me briefly turn to the text of Contributions itself.

Contributions (written 1936 to 1938) was published only relatively recently in German (1989), and then translated into English twice, in 1999 and then again in 2012 (this gives you a sense of how important it is, or how important it was thought to be, in Heidegger's work). Heidegger asked that it not be published for at least a hundred years after his death, for fear of it not being understood (he said perhaps only four or five people in the world could understand it), likely because Contributions is highly obscure and enigmatic (even for Heidegger) and written in a semi-aphoristic style that jumps from theme to theme with seemingly no coherent order, revolving around six "joinings" or "fugues" (die Fugen, like the musical fugues), that attempt to say or enact the process of overcoming (or deconstructing) metaphysics, a project that, as we know, has its roots in Luther and his attack on the relationship between Christianity and Hellenic metaphysics. Indeed it is the task 
of Contributions to somehow phenomenologically enact this overcoming by thinking through metaphysics' unthought ground or condition for possibility, which is none other than "beyng" itself. Thus the thinking of metaphysics' conditions is tantamount to thinking beyng, and yet thinking beyng proves impossible for Heidegger, so long as the concealed nature of beyng remains unthought. Therefore, in order to think beyng, qua truth, as the process of revealing and concealing, or "clearing concealing," attention must be paid to concealment, which itself remains concealed, as "concealed concealment," in metaphysics and metaphysics' various historical instantiations. In order then to "think concealment," beyng itself must be recognized in its "ironic" nature; that is, beyng must be seen as having a tendency to conceal itself in favor of beings. There is a distance between beyng and how beyng appears. In other words, the tension between essence and appearance, the very tension that characterizes irony itself (I'm thinking e.g. of Kierkegaard's treatment of irony), must be seen as inherent in the beyng/truth process of revealing/concealing, in that no single historical "meaning" of being is equivalent or identifiable with beyng itself, but rather "beyng" always holds back, conceals itself, in every historical revealing. This amounts to beyng's irony, that beyng always hides in order to "illuminate beings." Now this irony is precisely what is missed by metaphysical thinking, which began with Plato (in what Heidegger calls the "first beginning") and has now exhausted itself and come to its full fruition and climax in the Nietzschean reversal of Platonism, in the metaphysics of will to power, which understands things as objects to be mastered ("we are masters and possessors of nature" as Descartes had hoped for). This current situation Heidegger calls nihilism, or the "abandonment of being" in Contributions, and by this nihilism Heidegger means quite simply the reduction of the meaning of being to one meaning, such that beyng itself is concealed in the very reduction. That is, such reductionism is, for Heidegger, contingent upon the failure to recognize beyng itself - beyng's concealment - and thus the failure to recognize, as Aristotle says, that being is said in "many ways," has multiple meanings, and thus simply cannot be reduced to one meaning.

Now strangely enough, for Heidegger, to admit this is already to have begun, in a sense, to overcome metaphysics, insofar as overcoming metaphysics is nothing more than uncovering its conditions (this is of course the Kantian element in Heidegger's thinking). That is, once we've admitted that metaphysics is a reductionism that 
misses concealment -that conceals concealment - and fails to recognize beyng's irony, we've already begun to think past and to transcend such a reduction. Heidegger writes, in perhaps one of the most important passage of the Beiträge:

The question, what is metaphysics?, already inquires into what is essential to 'metaphysics' in the sense of gaining an initial footing in crossing to the other beginning. In other words, the question already asks from within this other beginning. What it makes visible in its determination of 'metaphysics' is already no longer metaphysics, but, rather its overcoming.

In other words, to inquire into metaphysics' grounds is already to transcend metaphysics to another beginning of post-metaphysical (or, meta-metaphysical) thinking. Asking about metaphysics then means deconstructing it and discovering beyng and beyng's self-concealment. Overcoming metaphysics and deconstruction then say the same thing, in a tautological manner, namely the "thinking of concealment," or recognizing beyng's fundamental irony with regard to itself. Beyng shows itself, but hides itself in its very showing, and if we can "think" this hiding, we can overcome or "twist free" of metaphysics. As we shall see, Heidegger will in Contributions equate the thinking that thinks concealment with faith itself.

Yet how does such a thinking occur? How can the human being become "Dasein" and thus think through this current nihilism? (Note: in Contributions the human being is no longer Dasein, but must become Dasein in the overcoming of metaphysics). Heidegger answers these questions as to "how" this remains possible in the final section of Contributions entitled "the last god." Here Heidegger describes a process wherein human beings would respond to the call of this last god, in the form of a hint, that would "echo" out of the concealed concealment of beyng in metaphysics and enable the human being,

I "Die Frage: Was ist Metaphysik?, im Bereich des Übergangs zum anderen Anfang gestellt..., erfragt das Wesen der 'Metaphysik' bereits im Sinne einer ersten Gewinnung der Vorfeldstellung zum Übergang in den anderen Anfang. Mit anderen Worten, sie fragt schon aus diesem her. Was sie als Bestimmung der 'Metaphysik' sichtbar macht, das ist schon nicht mehr die Metaphysik, sondern ihre Überwindung." M. Heidegger, Beiträge zur Philosophie: Vom Ereignis, Frankfurt 1989, p. I7I-I72 (Gesamtausgabe, 65); translation mine. 
in distress (die Not), to enact a necessary turn (Not-wendig) and "leap" out of this nihilism into the groundless ground (or abyss) that is the concealment of beyng itself. Here Heidegger is rethinking authenticity (Eigentlichkeit) from Being and Time, in terms of the event of beyng (Er-eignis, where Heidegger highlights purposefully the word "eigen"). Now, in Being and Time, Dasein is called by its conscience to authentically "own" its own being vis-à-vis das Man, by anticipating in anxiety its "ownmost possibility" - death. It seems however that this authenticity structure is simply a "demythologized" version of the very same structure used by Heidegger in his early lectures on St. Paul from the I920s. That is, in these Paul lectures Heidegger considers the early Christian as one who responds to a call, in distress and anxiety, and converts, turns, over and against "the world" (here the analog for das Man) and anticipates the futural not-yet of the Parousia of Christ (the analog for death). In Contributions these same existential categories (of the authenticity/faith structure) are rethought historically (rather than religiously or purely existentially) and are wedded to the overcoming of metaphysics. In Contributions, metaphysics (qua nihilism) functions as the inauthenticity of the current age and thus as the analog to das Man and the world. The authentic thinking of the event of beyng, amounts to responding to the call of the last god, in distress and anxiety, and functions as the analog to authenticity and faith. Most importantly, the last god functions as the analog to both the Parousia and death, both of which remain essentially futural and hence must be anticipated in existential anxiety or distress. Thus, the very same existential structures that Heidegger first presented in his analysis of primordial Christianity remain almost completely intact in his thinking of the last god in Contributions. Moreover, in his initial phenomenology of early Christian existence, Heidegger sought to divorce enacted Christian existence from a kind of objectivism and dogmatism that he thought burdened the (then) current trends in philosophy of religion. In the same way, Heidegger's thinking of the last god attempts to divorce itself from the onto-theology of metaphysics that seeks to corner God into the category of being and ground, where the last god is simply the presence of the holy as it appears or manifests itself (i.e. comes to have meaning within a world as an open relational context of meaning) out of the negative or concealed dimension of existence (being) when and only when metaphysics is overcome by thinking through the conditions for its possibility. 
So, how are these elements of the authenticity structure and the overcoming of metaphysics in Contributions Lutheran; that is, how do they display a Lutheran "metaphysics"? Firstly (and obviously) the general project of overcoming metaphysics by way of a deconstruction of it, as we know, has its roots in Luther's "deconstruction" of Athens' marriage to Jerusalem, in Luther's opposing of the "theology of glory" by way of a "theology of the cross," which results in not only an attack upon Greek metaphysics (specifically Aristotle), but also upon reason (ratio) itself and the very rational categories by and through which we understand things in the world. In general, Luther attacks reason, famously characterizing it as the "Devil's Whore" that must be "slain by faith," largely due to the corruption of reason by the far-reaching effects of original sin, which render reason unable to think the invisible God apart from idolizing the visible creation. In other words, Luther's attack on reason amounts to, at least in part, an attack on natural theology, and thus a reinterpretation of Romans r:19-20 ("God's invisible qualities are clearly discerned from what has been made"). Thus, Luther argues, quite fideisticly, that one must "kill reason and believe in Christ," and embrace the mystery of God's absence, God's abandonment, which must be endured in Anfechtung (tribulation, affliction).

However, Luther's attack on theoretical reason gets much more specific in his commentary on Romans (specifically v. 8:19), as it attacks the very nature of metaphysical speculation itself, namely ontology, temporality, and the doctrine of essences. Luther argues that philosophers in their preoccupation with the quidditative presence of things, privilege the temporality of the present, or how creatures "are now," over and against that of the future as to how things "will be" at the Eschaton. Vis-à-vis this "metaphysics of presence," Luther advocates a "me-ontological negation" of things as they "are" in favor of what they "are not" and thus "will be," in order to shift the focus from creatures "as such" toward what creatures "wait for." Luther writes,

[L]earn from the apostle to consider the whole creature as it waits, groans, and travails in pain, i.e., as it turns with disgust from what now is and yearns for what is to come. Then the science of the essence of things and of their accidental qualities and differences will soon become worthless... anyone who searches into the essences and functionings of the creatures rather than into their sighings 
and earnest expectations is certainly foolish and blind." (Romans, $236-237) .^{2}$

Luther thus argues for what he calls, later in that same passage, "tensed hoping" over "theoretical speculation." Indeed, Luther translates apokaradokia (from Romans 8:19, "the creation waits in eager expectation for the sons of God to be revealed") as ängstliche Harren, i.e. anxious waiting or anticipation. Luther's anti-metaphysical posture thus advocates a meontological or negative futural comportment of anxious anticipation towards beings and towards God.

Now from a quick glance, Lutheran themes such as the critique of metaphysics and of natural theology, the privileging of the future over the present, and the emphasis upon anxiety and anticipation, all appear to be fairly explicit not only in Contributions, but also throughout most of the Heideggerian corpus. As we have seen, Contributions' focus is upon the overcoming of the metaphysical conception of being (as of course Beingness or presence), and awaiting, in distress and anxiety, the last god as-to-come. Indeed, the futural last god is the messianic itself, whose coming is contingent upon the recognition of the concealment of beyng itself. Such a comportment of anticipation, in anxiety, towards a futural not-yet within the context of an overcoming of metaphysics is clearly reminiscent of Luther's commentary on Romans. Moreover, although not explicit, much of Contributions anticipates Heidegger's later critique of onto-theology, which argues that "God" is blasphemed so long as God is thought through the causal-nexus of ratio with its categories of substance and causality. That is, for Heidegger, once beings are conceived as substances within a causal nexus, ipso facto this nexus leads (in order to avoid infinite regress) to a terminus, in an unconditioned cause, that is simultaneously substantive in the highest sense. In other words, the conceiving of beings under the rational, metaphysical categories of cause and substance always leads to the eventuality of the Scholastic hierarchy and/or analogy of being, where beings are caused by the highest cause, God, which Heidegger, like Luther, considered blasphemous. Heidegger's onto-theological critique then demands an assault upon reason (in terms of its metaphysical blasphemy in the analogy of being) and thus reposes the famous Tertullian question concerning Athens' relationship to Jerusalem, or reason's

2 M. Luther, Lectures on Romans, Philadelphia I96I, p. 236-237. 
relationship to faith. Heidegger of course does not go so far as to call reason the "devil's whore;" however, Heidegger does, like Luther, direct this critique precisely at reason itself (and the doctrine of analogy), and in turn posits a conception of God that remains hidden and absent, always futural, and one that must be endured in distress and anxiety (or we could say in Anfechtung). The last god, as the Deus Absconditus, avoids, perhaps fideistically, the rational pitfalls of metaphysics and its blasphemous God "of the philosophers," by showing itself as concealed, and moreover, showing itself only in tandem with metaphysics' deconstruction, or with the thinking of concealment that thinks through metaphysics' own conditions for possibility. It is to this simultaneity between the last god and the deconstruction of metaphysics that I'll now turn. (It is worth noting parenthetically that since I believe that Heidegger's onto-theological critique is fully a result of this "Lutheran logic," and since so much of current postmodern, Continental philosophy of religion simply presupposes Heidegger's onto-theological critique, I have therefore argued elsewhere that all postmodern theology or philosophy of religion is fundamentally Lutheran). ${ }^{3}$

The decisive Lutheran element of Heidegger's Beiträge is not simply the last god, but the last god occurring in tandem with the overcoming of metaphysics and the fundamental comportment of the human being towards reality, which I argue, is fundamentally an ironic posture that Heidegger usurps from the logic of Luther. As said above, the last god is wholly wedded, for Heidegger, to the overcoming of metaphysics, so much so that Heidegger even says explicitly that the last god is the overcoming, is the "other beginning" beyond metaphysics. Thus this disentanglement of God from ratio proves essential for Heidegger, as it did for Luther, in order for authentic faith to occur. As I noted earlier, the primary aim of Heidegger's Contributions is to "think concealment" so as to overcome metaphysics, which involves a recognition of beyng's own irony, i.e. its ironic withdrawal with regard to its historic instances. Moreover, Heidegger calls the comportment towards this ironic concealment of beyng nothing other than "faith," and thus it is here that Heidegger's deepest connections to Luther, in Contributions, come to the fore.

3 See D. Armitage, Heidegger's Pauline and Lutheran Roots, New York 2016, p. 153-I67. 
Heidegger argues, toward the end of Contributions, that the essence of faith must be grasped "on the basis of the essence of truth" and distinguishes between two aspects of faith: on the one hand, a faith that holds or believes what is true, e.g. the assent to some creedal formula, and on the other hand, a more original faith that holds to truth itself, and not merely to what is true. ${ }^{4}$ That is, true faith is synonymous with what Heidegger calls an "essential knowing" that stands in the truth of beyng itself, which is nothing more than to recognize the concealment of truth itself, or the concealing in the "clearing-concealing." Heidegger writes,

If the essence of truth is the clearing [ Lichtung] for the self-concealing of beyng, then knowledge [qua faith] is an abiding in this clearing [or revealing] of concealment and is thus the basic relation of the selfconcealing of beyng and to beyng itself. 5

Faith stands from within the essence of truth, that is, from within the negative, concealing dimension of truth and thus to the self-concealing of beyng itself. Yet, to stand from within concealment and to think such concealment, is already, as we have seen, to have overcome metaphysics (insofar as metaphysical thinking missed this very concealment). Thus, such faith, which abides in the "clearing concealment," harkens to and recognizes truth/beyng's self-effacing irony in metaphysics, and thus allows for the overcoming and self-destruction of metaphysics. That is, metaphysics by way of metaphysics, is destroyed, insofar as metaphysics is seen in its truth, namely as an (ironic) showing of beyng. Faith thus enables metaphysics to be transcended by way of itself, when its conditions are recognized; metaphysics therefore dismantles itself by way of the posture of faith (that recognizes beyng's own irony). In other words, faith transcends (and thus negates) metaphysics, by recognizing precisely what was held back and concealed in it, namely beyng itself; this transcendental negation is tantamount to the recognition of beyng's ironic withdrawal.

Now in Luther we see this same fundamental, ironic posture of $\mathrm{fa}-$ ith, in his doctrine of sola fide, where faith is contingent upon first a recognition of what Kierkegaard later calls "the irony of the law," namely

4 M. Heidegger, Contributions to Philosophy, Bloomington 2012, p. 291.

5 M. Heidegger, Contributions to Philosophy, op. cit., p. 292. 
that the Mosaic law, in all that it commands, commands ironically, in that it commands what no one can fulfill, and moreover actually incites one under the law to do the opposite (as St. Paul says "I did not know what it was to covet until the commandment came, and then sin came alive and I died" (Romans 7:7-9)). If irony is characterized by a distance and difference between essence and appearance, where, in this tension, appearance reveals not its essence but the opposite thereof, then the law proves ironic in that while its end (telos) is to make a person good, what results from it is the opposite, namely sin and death. A necessary component and step in "saving faith" involves, for Luther, then a recognition of the Mosaic law's own self-destruction in its own irony. Once one recognizes the impossibility of fulfilling the law, then and only then can saving faith enter as one confronts one's own impotence before the law. Luther writes,

...[T] he commandments show us what we ought to do but do not give us the power to do it. They are intended to teach man to know himself, that through them he may recognize his inability to do good and may despair of his own ability...when a man has learned through the commandments to recognize his helplessness and is distressed about how he might satisfy the law...then being truly humbled and reduced to nothing in his own eyes, he finds in himself nothing whereby he may be justified and saved....this is the first power of faith. ${ }^{6}$

The law thus begins to destroy itself the moment it is taken seriously. One only has to attempt to fulfill the law to recognize the irony that the law cannot and can't ever be fulfilled. The law therefore self-destructs. Faith's requisite then is a deconstruction of the law, in that faith first requires a comportment toward the law that allows for the law's own destruction through a recognition of its own irony. Such a conception of faith is mirrored in Heidegger's Contributions insofar as faith is precisely the fundamental ironic posture of negation that allows for metaphysics' own self-deconstruction and unraveling precisely by the recognition of its own irony, namely the irony of beyng. Moreover, this ironic posture also results in a negating of what is in favor of what is to come, which must be awaited and endured in anxiety and distress. Again,

6 M. Luther, Selections from His Writings, ed. by J. Dillenberger, New York I962, p. $57-59$. 
Kierkegaard's conception of irony (as fundamentally an act of deconstruction by way of negation) can help mediate here: for Kierkegaard, the ironist negates or destroys the given actuality by the given actuality itself; that is, the ironist negates by letting the given reality self-destruct or deconstruct itself by finding within actuality the seeds of its own demise, which means the ironist does not advance the new so much as enable the old to be perceived in its incompleteness and imperfection, and thus the given actuality loses its validity and meaning. Kierkegaard of course assumes the Hegelian dialectic of history, where the Idea becomes more and more actual through various dialectical movements of the coming of the new and the displacement of the old. The ironist applies to the latter, as his role is to displace and negate the current actuality, without however aiding or even knowing of what is to come. Irony is thus simultaneously an act of negating and awaiting. This maps onto the ironic postures of Luther and Heidegger, where the law and metaphysics lose their validity and are displaced once their truth is recognized, and the new, which is to come, is anticipated. In other words, Kierkegaard shows that the activity of deconstruction is precisely the same activity of irony, i.e. the recognition that something is "held back" that cannot be thought or even found, but only awaited.

The overcoming of reason and Greek metaphysics, as well as the Mosaic law, through an ironic, deconstructive comportment that would negate "what is" in favor of "what is to come" in the tensed hope of anxious anticipation, is thus what unites Heidegger's Beiträge to Luther's "metaphysics." Heidegger's "Lutheran roots" are then not simply the structural similarities of anxiety and distress in anticipation of the messianic, but also the fact that such structural similarities occur within the context of simultaneously deconstructing metaphysics (and Judaism) so as to enable the ironic and anticipatory nature of faith itself. Heidegger's use of Luther's existential categories and deconstructive aim makes it difficult to interpret the "logic" to Heidegger's "theology" in Contributions, as well as his later philosophy, as anything other than "Christian," and thus seems to situate Heidegger's project, at least theologically, within the Reformational thinking that attempts, like Kierkegaard and Kant, to delimit reason in order to make room for faith. However, any deconstruction of rationality, whether in in favor of saving faith or phenomenological "faith" qua Denken, nevertheless may lead not only to a deconstruction of reason, but to a destruction of it as well. This destruction of reason results in the common charge against 
Luther (and against Kierkegaard) of fideism. That is, any deconstruction of reason presupposes the very thing it attempts to deconstruct, and would then deconstruct itself as well, self-referentially, insofar as even descriptive phenomenology and/or faith hermeneutics presupposes the very rational categories (of "cause," "substance," etc.) that would remain dismantled and rendered inert by the deconstruction. The question remains as to whether Luther's (and Heidegger's) critique of metaphysics and reason can exempt itself from its own critique, or inadvertently destroys even its own claims to truth by deconstructing truth's very condition(s) for possibility, namely rationality itself.

\section{BiBLIOGRAPHY}

Armitage D., Heidegger's Pauline and Lutheran Roots, New York 2016.

Luther M., Selections from His Writings, ed. by J. Dillenberger, New York 1962.

Luther M., Lectures on Romans, Philadelphia 196r.

Heidegger M., Contributions to Philosophy: Of the Event, trans. by R. Rojcewicz, D. Vallega-Neu, Bloomington 2012.

Heidegger M., Gesamtausgabe 65: Beiträge zur Philosophie: Vom Ereignis, Frankfurt 1989 . 